\title{
The Role of the Party in the Chinese Post-Mao Reform Process
}

SU SHAOZHI

Before liberation, China was under the oppression of imperialism, feudalism and bureaucratic capitalism, and its people lived in a humiliating state for a long time. Its economy and culture was very backward. Many people with lofty ideals sought a path to save the nation and the people, but they all failed. After the establishment of the Chinese Communist Party (CCP), where the objective was to integrate Marxism with Chinese reality, the Party led the people to overthrow the rule of imperialism, feudalism, and bureaucratic capitalism, and won the victory of the new democratic revolution. The role of the Party in the Chinese national liberation was eminent and obvious to all.

Since the inauguration of the People's Republic of China (PRC) in 1949, the leading role of the Party has not been an accidental phenomenon, but the inevitable result of historical developments. If the leading role of the Party is understood as expressed officially today: "The Party exercises political leadership, which means that it formulates political principles, points out the political direction, and makes major policy decisions, « ${ }^{1}$ and if the Party had followed a democratic style of work and constantly heeded the opinions of the masses, the leading role of the Party would have been correct and effective. But because of the historical conditions the leading role of the Party was cast according to the traditional theory of Party construction into a monolithic, overwhelming, and absolute one. As Mao Zedong said: „Industry, agriculture, commerce, academy, and military; east, west, south, north, and central, all is under the leading role of the Party. «Or, as Moshe Lewin said about the Stalinistic system in the Soviet Union - there are two triads: »the triad of Party - state - economy « ${ }^{2}$ and "the triad of power - ideology - culture. $\aleph^{3}$ Because it is easy to run any affairs in a government under high centralization, two situations may develop. If the leading role of the Party is correct, conforming to reality and objective laws, it will quickly promote the socio- economic development of a country. If it is incorrect, it will obstruct and harm this development. Under the existing socialist system, without a mechanism to guarantee the 
correctness of the ruling Party, especially when its power is concentrated in a few persons or even in one person, a personality cult can appear. Mistakes and devastating effects of the Party will be inevitable. The painful experiences of China after the establishment of the PRC are a case in point. Other socialist countries followed the same path.

If we want to study the role of the Party in China's reform process, including the question of what role the Party should have, we must start with the role of the Party in the establishment and development of the existing socialist society.

Within the decade after the inauguration of the PRC, through the period of the recovery of the national economy and the period of transformation of private ownership into public ownership, under the leadership of the Party, the socialist system was basically established. This kind of socialist system is basically the same as the socialist system of all the socialist countries before reform. That is, a "command system « both in terms of its "command politics « and its »command economy. « We usually call it "real existing socialism, " distinguishing it from what Marx and Engels envisaged to be "scientific socialism. "In present documents of the Chinese Communist Party, it is usually called the "old structure. " In the "old structure" in China, as Zhao Ziyang once described it, sa structure of ownership evolved, in which undue emphasis was placed on a single form of ownership, and a rigid economic structure took shape, along with a corresponding political structure based on over-concentralization of power. «

\section{The Role of the Party and the "Old Structure"}

The defects of the »old structure « have been widely discussed. What I want to examine here is, how it was formed, and what the role of the leadership of the Party was in its formation, in order to find the path of reform and see how the Party can improve its leadership in the reform process.

In regard to the formation of the »old structure, "Zhao Ziyang said in his report delivered at the 13 th National Congress of the CCP, »Our current political structure, which took shape during the revolutionary war years, was basically established in the period of the socialist transformation. It developed in large-scale mass movements and in the process constantly intensified mandatory planning. " ${ }^{6}$ With respect to the economic structure he said: "In the past, too many mandatory targets were assigned to enterprises directly by the state, the state had a monopoly on purchase and 
marketing, and goods were distributed according to a system of supply based on payment in kind. Some of these practices were followed in order to speed up the establishment of an industrial base under the conditions that existed both at home and abroad in the early days of the People's Republic; others had been handed down from the years of revolutionary war. They were not fixed practices that were necessitated by the socialist system. " ${ }^{7}$ Zhao Ziyang did not mention that the «old structure « was established under the guiding ideology of the Party, which was taken for granted.

In analyzing the formation of the current system, it seems that the leading role of the Party in the establishment of the »old structure « is mainly determined by the following points:

1) How to understand the theory of socialism of Marxism: China's socialist system is established on the theoretical model of socialism which the Party advocated for a long time. One aspect of this system is that public ownership of the means of production is held to be the only economic base of socialism; the principle that »to each according to his work « is the only principle of distribution of consumer goods; socialism is a sternly planned economy which runs exactly as a big machine; it is without commodity and money, as commodity economy is inconsistent with socialism; class struggle and proletarian dictatorship persist throughout the whole period of socialism. Of course, in this respect, the conceptualization includes the copying of the Soviet model.

2) What development strategy the Party adopted after the revolution: China, as other existing socialist countries, had a backward economy with a predominant agricultural sector and a big rural population, in which small-scale production was the mainstay. Nation-wide industrialization became the main development strategy after the 1949 revolution and the policy of industrialization gave priority to the development of heavy industry. Lacking capital to finance the programme of industrialization, China found it unavoidable to proceed by socialist primary accumulation. The source of capital accumulation could only be the products of the peasants and workers. Under such a development strategy, on the one hand, part of the fruit of the peasants' labour was in fact expropriated and the workers' wages were deliberately kept low. We know that in the existing socialist countries the wages of workers are less than the values of their 
labour force. On the other hand, consumer goods production was neglected, and people could only afford a low standard of living. Therefore, a high level of centralization both in economical and political affairs was unavoidable. Besides, in a country where the greater majority of the population are peasants, such a "command system " was easily accepted and was sometimes thought of as the only feasible solution.

3) The Party was given a dominant role also because of the leftist habits of thought emphasizing the transformation of relations of production and impatience about the transition into Communism. China, like other existing socialist countries, was before revolution in a state of relatively backward productivity and at a low level of economic development. After the revolution, it was felt necessary to emphasize the development of productive force and to catch up with the lessons of the commoditization, socialization, and modernization of production. The country needed a quite long period of transition before it could enter socialism, and it could only proceed in successive stages, step by step. But over the years, the guiding principle of the Party was transformation of relations of production, so that the country could transit into socialism - even Communism - overnight. Early in 1936, Stalin declared that the Soviet Union had completed the stage of socialism and was hastening towards Communism step by step. Following the slogan of "run into socialism, ". China proclaimed the basic establishment of socialism in 1956. Later the Party continuously emphasized class struggle and the transformation of relations of production, and launched the "great leap forward" and the "people's commune movement." This kind of mass movement, which was launched "from above« and developed in such a large scale, showed that the guiding principle and working method had a leftist tendency. In fact, both the Soviet Union and China should never be called socialist, judging from the low level of development of the productive forces, the poor qualifications of the people, the lack of democracy, and the serious defects of bureaucracy; at most they might be called "early socialist. "Leftist theorists forget Marx's principle that the new social formation can be born only after it has ripened in the womb of the old society. The Party line and policies, which are based on the leftist thought of hurried transition, only hampered and undermined social production.

4) Owing to China's historical conditions, remnants of feudal-despotic 
thought and the habits of small producers are bound to have a strong influence. They provide a hotbed for personality cult, "one man form « and an equalitarianism on which the »old structure« was based.

\section{The Role of the Party in the Reform Process}

Because the establishment of the »old structure« was under the guiding ideology of the Party at that time, if the guiding ideology of the Party does not change, even if some new ideas of reform emerge »from below, « they will not be given credit, but resisted or labelled as heresy. In China, from the »anti-rightist movement « of 1957 to a series of political campaigns from 1962 onward under the slogan of class struggle, a leftist ideology prevailed as I have analyzed above. A Chinese proverb says, $\gg$ He who ties the bell to the tiger's neck must take it off himself. "This means that whoever started the trouble is responsible to end it. So, if at the beginning the Party, as the ruling Party of the whole country, does not advocate reform »from above, « it will be impossible to have any reform. Not only in China, but in all the existing socialist countries, the leading role of the Party in reforms is singularly important.

The defects of the Chinese »old structure « developed to the extreme, and at last brought the Chinese people a disastrous "cultural revolution. "The »cultural revolution « proved the bankruptcy of the »old structure. «Reform became a general demand of the masses, and also a necessity for social development. The CCP followed the demand of the people and the objective laws of social development, summed up the lessons, and at the 3rd Plenum of the 11th Central Committee it called for sa change in the relations of production and super-structures which do not suit the productive force in many respects. " ${ }^{8}$ It also put forward the idea of "emancipating the mind, making great efforts to study new situations, new affairs, and new problems, persisting in the principle of seeking truth from facts, starting everything from reality, and integrating theory with practice. $"$ Thus, in fact, sounded the clarion call for an economic reform and a political reform. This was another major historic step forward in integrating Marxism with reality in China. ${ }^{10}$

In China's reforms today, the leading role of the Party is still very important. This feature is different from the Party's monolithic, comprehensive and absolute leadership that was the case earlier. Nor is it like in the past when everything was decided by the Party, and when things were all in 
the hands of the Party alone, without consulting the people. In the reform process the leading role of the Party manifests itself in the following aspects:

\section{To take a correct attitude and understand Marxism}

The CCP takes Marxism as its guiding ideology. If it cannot take a correct attitude and understand Marxism, it cannot correctly guide its practice. Under the present conditions, the most important practical tasks are the reforms. Over quite a long period, Marxism has been oversimplified, ossified, and dogmatized. As a result, the Party's scientific spirit and creativity have been suppressed. In order to remedy this situation, the CCP has done much work.

At the 3rd Plenary Session of the 11th Central Committee (December 1978), the CCP put forward "the principle of emancipating the mind, making great efforts to study new situations, new affairs, and new problems, persisting in the principle of seeking truth from facts, starting everything from reality, and integrating theory with practice. ${ }^{11}$.

A commentary in the Renmin Ribao of December 7, 1984 said: "We cannot ask the works of Marx and Lenin to solve all the problems we face today. « ${ }^{12}$

A resolution of the Central Committee of the CCP on the "Guiding Principles for Building a Socialist Society with an Advanced Culture and Ideology« (September 28, 1986) said, »It would be impossible to uphold Marxism if we rejected the overriding importance of practice and the need to observe reality from a developmental perspective and to bring forth new ideas. $\ll^{13}$

Zhao Ziyang in his report to the 13th Party Congress said, sIt is only natural that the people will discard some theses which are utopian because they were formulated by our predecessors within the limits of their historical conditions. It is also natural that the people will reject dogmatic interpretations of Marxism and erroneous viewpoints imposed on it, and will further develop the theory of scientific socialism on the basis of new practice. ${ }^{14}$

We cannot imagine how, during the period in which Stalinism prevailed, the period of the personality cult of Mao and the period of stwo whateverism; " we could have promoted any reform. Only when we had rejected the personality cult and the concentration of power to one single 
person, and had discarded utopian ideas, dogmatism, and misinterpretations of Marxist works, could we proceed from reality and develop a series of scientific theoretical ideas. But we cannot change our ideology without making an effort. During the process of reforming its ideology China has faced enormous obstacles and opposition. Obstructed by traditional forms of thinking we have not done well in certain fields, for example, in criticizing Stalinism and Marx's wrong ideas. The result is that China's ideological reform is faced with many difficulties.

\section{To rethink socialism}

We should adopt a correct attitude towards Marxism and deepen our understanding of Marxism. This will enable us to use a genuine Marxist standpoint and methodology to rethink socialism. We should consider what is right and what is wrong in our previous understanding of socialism by taking reality as the criterion. We should not rely on the old ideas of socialism prevailing in the 1930 s and 1940 s to judge today's reform. We should not use the old perspective to question whether certain measures of reform are socialism or capitalism, thereby obstructing reform. The CCP has done much work to encourage people to rethink socialism. After the 3rd Plenary Session of the 11th Central Committee many new thoughts which fit the requirements of social progress have emerged. But this is not enough; in certain fields new ideas are still tabooed, for example the problem of alienation in a socialist society.

\section{Clearly to recognize the socio-historical stages of contemporary China} Previously we were not so clear in our minds about what historical stage we lived in, which led to the emergence of false leftist tendencies. Today, the CCP applies Marxism to analyze the present conditions in China and draws the conclusion that China is in the primary stage of socialism. We recognize that China's productivity is quite low. China's socialization of production, which is essential for expanded socialist public ownership, is still limited in scope, and China's commodity economy and domestic market are only beginning to develop; China's natural economy and seminatural economy constitute a considerable proportion of the whole; and China's socialist economic system is not yet mature and well developed. "In the realm of the superstructure, a number of economic and cultural 
conditions that are necessary if we are to promote a high degree of socialist democracy, are far from ripe, and decadent feudal and capitalist ideologies, and the small producers' force of habit still have widespread influence in the society and often corrode Party cadres and public servants. $\aleph^{15}$ All this makes it inevitable that we have a long way to go during the primary stage of socialism in order to achieve the commoditization, socialization, and modernization which the developed countries have achieved under the conditions of capitalism, and in order to achieve a tremendous development of productivity. This thesis criticizes the leftist tendency of pushing through the transition period, gets rid of the epistemological roots of the leftist tendency, and serves to smash the trammels of »left « ideas. It also clears the way for formulating correct lines and policies. What remains to be done is to clear away thoroughly the wrong leftist tendency, especially in the ideological sphere.

\section{To formulate a socio-economic development strategy on the basis of present Chinese reality}

The CCP has summed up the experience and lessons in economic construction from the inauguration of the People's Republic to the present, and has formulated a new socio-economic development strategy. The Party has decided that the focal point of the work of the whole country should be redirected to socialist construction, and that the basic role of socialism is in developing productivity. In the primary stage of socialism, the task of developing social productivity includes efforts to bring about industrialization and commoditization, and the socialization and modernization of the production. In order to enhance the prospects of socialist modernization in China, we must proceed on the basis of integrating the basic principles of Marxism with Chinese reality, adhering to the guidelines of building socialism with Chinese characteristics, implementing fully the policy of vitalizing the economy at home and opening up to the outside world, in order to speed up the pace of overall economic reforms with urban areas as the focal point. To formulate a socio-economic development strategy which tallies with the present condition, and to unite the whole nation to strive for reform and modernization - this is a most important measure. 


\section{To improve the leadership of the Party, to implement the reform of the} political structure, to develop democracy fully, and to mobilize the masses to support the reform

The experiences and lessons which China has gained since the inauguration of the reforms tell us that without political reform the economic reform cannot succeed in the end. Because the CCP is the core of leadership in China's socialist cause, a reform of the Party itself is in the forefront of political reform. Reform is a systematic project, both reform and modernization are the objective of the whole people. To arouse the enthusiasm of the masses is to assure the success of this cause. To this end the Party must implement a reform of the Party itself in light of the new situation. The Party should improve its leadership system, its methods of leadership and its style of work. Most importantly, the Party should develop intra-party democracy, run the Party strictly, and strive to ensure the honesty of the members and organs of the Party and of the government. Then, as a further step, the Party should develop a people's democracy, allowing the people to become the real masters of our country, to enjoy the right of citizenship of all kinds and to participate in the management of the state and enterprises as a matter of right. The Party should enrich its democratic life through formal measures and institutionalization, and increase the transparancy of politics. When the masses become real masters, they will support the reform from the bottom of their heart, and the success of the reform will be guaranteed. This is a most important aspect of the Party's work during the country's reform.

\section{Concluding Remarks}

We hold that the leading role of the Party refers to its "political leadership, which means that it formulates political principles, points out the political direction, and makes major policy decisions. ${ }^{16}$ During the period of reform the CCP has played its role according to this principle. Specifically, this role embraces the above five aspects. In some of these aspects the Party has done well and has achieved some results. But the reform is an ongoing process and is developing further. Due to obstruction from the force of habit and conservative thinking, many problems about the Party and the country have not been clearly solved. As a result, we have not done very well; our reform faces more twists and turns, stops and stagnations. We 
have much work to do, before we can make our reform a complete success.

Su Shaozhi is currently visiting scholar at The Bradley Institute for Democracy and Public Values, Marquette University, USA. From 1981-1987 he was director of the Institute of Marxism-Leninism-Mao Zedong Thought, Chinese Academy of Social Sciences. This is a lecture delivered at the Center for East and Southeast Asian Studies, University of Copenhagen, in the month of October 1988.

\section{NOTES}

1 Zhao Ziyang, "Advance Along the Road of Socialism With Chinese Characteristics, "Beijing Review, 1987, No. 45 , p. XVI.

2 Moshe Lewin, The Gorbachev Phenomenon: $A$ Historical Interpretation (Berkeley: University of California Press, 1988), p. 109.

3 Ibid., p. 113.

4 Zhao Ziyang, "Advance Along the Road of Socialism With Chinese Characteristics, « p. III.

5 . Ibid,, p. IV.

6 Ibid., p. XXI.

7 Ibid., p. XI.

8 «Communique of the 3rd Plenary Session of the 11th Central Committee of

the Communist Party of China, "Peking 16 Ibid., p. XVI. Review, 1978, No. 52, p. 11.
9 Ibid., p. 14.

10 Zhao Ziyang, "Advance Along the Road of Socialism With Chinese Characteristics, " p. XXV.

11 «Communique of the 3rd Plenary Session of the 11th Central Committee of the Communist Party of China, « p. 14.

12 Renmin Ribao, December 7, 1984.

13 «Resolution of the Central Committee of the CCP on the Guiding Principles for Building a Socialist Society with an Advanced Culture and Ideology, " Beijing Review, 1986, No. 40, p. VII.

14 Zhao Ziyang, "Advance Along the Road of Socialism With Chinese Characteristics, «p. XXV.

15 Ibid., p. IV. 